\title{
PENERAPAN METODE EVERYONE IS TEACHER HERE DALAM MENINGKATKAN KUALITAS PEMBELAJARAN PAI PADA SISWA KELAS XI SMA NEGRI 1 KOTA BOGOR
}

\author{
Firda Pratiwi, Dira Yolandari, Rayhan Nur Azizah \\ firdapratiwi1704@gmail.com \\ Mahasiswa Fakultas Agama Islam Universitas Ibn Khaldun
}

\begin{abstract}
ABSTRAK
Penelitian ini merupakan penelitian eksperimen yaitu menguji coba metode Everyone Is Teacher Here dalam proses pembelajaran. Subyek dalam penelitian ini adalah siswa kelas XI SMA Negri 1 Kota Bogor yang berjumlah 33 orang. Sedangkan yang menjadi obyeknya adalah penerapan metode pembelajaran Everyone Is Teacher Here. Tujuan penelitian ini adalah untuk mengetahui perbedaan yang signifikan dalam meningkatkan kualitas pembelajaran PAI melalui penerapan metode Everyone Is Teacher Here. Tekhnik pengumpulan data dalam penelitian ini menggunakan hasil nilai kognitif dan keterampilan. Tekhnik analisis data yang digunakan adalah analisis statistik inferensial, yaitu tekhnik analisis Test " $t$ " data yang diperoleh dianalisis dengan menggunakan Test " $t$ " melalui program SPSS 16.0. Analisis data menunjukkan bahwa data penerapan Strategi Is Teacher Here diperoleh To $=5,535$ lebih besar dari Tt. baik pada taraf signifikan $5 \%$ Maupun $1 \%$. dengan demikian Ha diterima \& Ho ditolak. berarti ada perbedaan yang signifikan dari penerapan metode Everyone Is Teacher dalam meningkatkan kualitas pembelajaran PAI kelas XI SMA Negri 1 Kota Bogor. Berdasarkan hasil penelitian dari analisis data diperoleh kesimpulan bahwa metodei Everyone Is Teacher Here memiliki pengaruh yang signifikan terhadap kualitas belajar siswa kelas XI SMA Negri 1 Kota Bogor pada pembelajaran PAI . Metode every one is teacher here efektif dalam meningkatkan kualitas pembelajaran PAI.
\end{abstract}

Kata Kunci: kualitas pembelajaran, penerapan metode everyone is teacher here dan pendidikan agama islam.

\section{PENDAHULUAN}

Dunia pendidikan Indonesia dewasa ini dihadapkan pada masalah yang sangat kompleks. Kurangnya sarana pembelajaran, kurangnya kualitas dan kuantitas tenaga pengajar, maupun rendahnya motivasi internal dan eksternal anak sebagai objek pendidikan. Pendidikan sebagai proses yang aktif, dinamik, dan generatif memberikan sumbangan yang penting kepada anak dalam pengembangan soft skill anak seperti pengembangan nalar, berfikir logis, sistematik, kritis, cermat, dan bersikap obyektif serta terbuka dalam menghadapi berbagai permasalahan. Tercapainya pengembangan soft skill anak dipengaruhi beberapa faktor, antara lain faktor siswa, faktor lingkungan dan faktor guru. Guru sebagai fasilitator dalam pembelajaran, harus senantiasa mengupayakan peningkatan kualitasnya 
untuk mencapai kemajuan. Penggunaan model pembelajaran konvensional dimana pemahaman siswa lebih banyak dari menghafal konsep yang disampaikan guru akan sangat kesulitan untuk bisa mengembangkan soft skills siswa. Pada kondisi terkini, penggunaan metode pembelajaran yang tepat untuk pembelajaran di tingkat SMA akan mempengaruhi perkembangan life skill siswa.

Metode mengajar merupakan caracara menyajikan bahan pelajaran kepada peserta didik untuk mencapai tujuan yang telah ditetapkan. Metode itu sendiri merupakan salah satu sub system dalam sistem pembelajaran, yang tidak bisa dilepaskan begitu saja. Oleh karena itu, salah satu masalah yang sangat memerlukan perhatian dalam kegiatan pembelajaran adalah metode pembelajaran (learning method). Pada awalnya metode ini kurang mendapatkan perhatian, karena orang berpandangan bahwa pembelajaran itu merupakan suatu kegiatan yang sifatnya praktis. Jadi tidak diperlukan pengetahuan (teori) yang ada sangkut pautnya dengan pembelajaran. Pandangan ini tidaklah benar. Fasilitator perlu pula mempelajari pengetahuan yang ada kaitannya dengan kegiatan pembelajaran, khususnya metode pembelajaran, yang berguna untuk "bagaimana memproses" terjadinya interaksi belajar. Maka dari itu dalam makalah ini kami akan membahas hal - hal yang perlu di perhatikan dalam metode pembelajaran yaitu kelebihan dan keterbatasan metode pembelajaran, klasifikasi metode pembelajaran, dan pertimbangan pemilihasn metode pembelajaran.

Lembaga pendidikan bertujuan menyiapkan peserta didik yang beriman, bertaqwa kreatif dan inovatif serta berwawasan keilmuan dan juga
dipersiapkan pendidikan ke jenjang pendidikan yang lebih tinggi. Usaha menyiapkan peserta didik dalam mencapai tujuan tersebut diperlukan seperangkat pembelajaran yang di berikan kepada siswa termasuk didalamnya mata pelajaran agama. Pendidikan Agama Islam mempunyai peranan penting dalam tujuan pendidikan nasioanl. Untuk itu Pendidikan Agama Islam haruslah membenahi diri dengan cara meningkatkan kualitas sehingga bisa mencapai tujuan pendidikan nasional. Kualitas Pendidikan Agama Islam merupakan hal yang sangat mendasar yang harus diperhatikan sehingga dapat di jadikan media untuk mencetak sumberdaya manusia yang mampu untuk bersaing dengan lingkungannya, serta bisa merealisasikan ilmunya ditengah-tengah masyarakat. Hal ini berarti harus ada keseimbangan antara imtak dan iptek. Untuk mencapai hal tersebut tentu banyak faktor yang mempengaruhinya, oleh karena itu perlu adanya berbagai upaya yang harus di lakukan dalam peningkatan Pendidikan Agama Islam. Mengingat pentingnya pendidikan Agama Islam maka kualitas pembelajaran perlu di tingkatkan. Untuk itu semua komponen yang terkait dalam proses pembelajaran pendidikan agama islam perlu di optimalkan. Kita ketahui bahwa keberhasilan proses pembelajaran sebagian besar tergantung kepada faktor guru sebagai pelaksana kurikulum dan penanggung jawab dalam kegiatan proses pembelajaran.Berdasarkan latar belakang masalah yang telah diuraikan sebelumnya, maka rumusan masalah yang diajukan dalam penelitian ini adalah bagaimana Implementasi metode everyone is teacher here dalam meningkatkan kualitas 
pembelajaran PAI kelas XI di SMA Negri

1 Kota Bogor?

\section{Tujuan Penelitian}

Kegiatan penelitian yang peneliti laksanakan bertujuan untuk meningkatkan kualitas pembelajaran PAI dalam proses belajar siswa kelas XI, juga menyiapkan peserta didik yang beriman, bertaqwa kreatif dan inovatif serta berwawasan

\section{METODE PELAKSANAAN}

Dalam penelitian ini kami menggunakan metode eksperimen. metode eksperimen adalah cara penyajian pembelajaran dengan suatu percobaan, mengalami dan membuktikan sendiri apa

\section{HASIL DAN PEMBAHASAN}

Setelah menyelesaikan kegiatan pembelajaran, kemudian dilakukan analisis data dari hasil penilaian pembelajaran. Penilaian pembelajaran meliputi aspek kognitif ( pengetahuan ), Afektif (rasa) dan Keterampilan. Penilaian pembelajaran dari aspek kognitif kami lakukan secara langsung dengan proses tanya jawab maupun hasil diskusi terkait materi PAI, Penilaian pembelajaran dari aspek Afektif kami melihat siswa bagaimana mereka merasakan kenyamanan dalam proses pembelajaran sehingga materi yang di sampaikan bukan hanya sebagai pengetahuan saja namun juga dapat di praktikan dalam kehidupan sehari-hari dan Penilaian pembelajaran dari aspek Keterampilan kami menilai dengan cara bagaimana cara siswa menyampaikan jawaban atas pertanyaan mengenai materi PAI yang sedaang berlangsung menggunakan metode Everyone Is Teacher Here. Setelah kami melakukan proses pembelajaran, pengamatan dan melakukan keilmuan dan juga dipersiapkan untuk melanjutkan pendidikan ke jenjang pendidikan yang lebih tinggi. Usaha menyiapkan peserta didik dalam mencapai tujuan tersebut diperlukan seperangkat pembelajaran yang di berikan kepada siswa termasuk didalamnya mata pelajaran agama karena pelajaran agama mempunyai peranan yang sangat penting dalam kehidupan.

yang dipelajari, serta siswa dapat menarik suatu kesimpulan dari proses yang dialaminya. Intervensi yang direncanakan setelah diagnosis yang rinci terhadap konteks masalahnya.

penilaian menggunakan post test inilah hasil dari pada nilai tersebut.

Nilai Kognitif kelas XI Mipa 7, Metode pembelajaran : Everyone Is Teacher here

Materi : Khutbah, Tabligh dan Dakwah

\begin{tabular}{|c|l|c|}
\hline 1 & Jumlah siswa & 33 \\
\hline 2 & Nilai maximum & 99 \\
\hline 3 & Nilai minimum & 90 \\
\hline 4 & Nilai rata-rata & 93.3 \\
\hline
\end{tabular}

Nilai Afektif kelas XI Mipa 7,

Metode pembelajaran : Everyone Is

Teacher here

Materi : Khutbah, Tabligh dan Dakwah

\begin{tabular}{|c|l|c|}
\hline 1 & Jumlah siswa & 33 \\
\hline 2 & Nilai maximum & 95 \\
\hline 3 & Nilai minimum & 88 \\
\hline 4 & Nilai rata-rata & 92.0 \\
\hline
\end{tabular}

Nilai Keterampilan kelas XI Mipa 7, Metode pembelajaran : Everyone Is Teacher here

Materi : Khutbah, Tabligh dan Dakwah 


\begin{tabular}{|c|l|c|}
\hline 1 & Jumlah siswa & 33 \\
\hline 2 & Nilai maximum & 98 \\
\hline 3 & Nilai minimum & 95 \\
\hline 4 & Nilai rata-rata & 95.0 \\
\hline
\end{tabular}

Nilai Kognitif kelas XI Mipa 5

Materi : Khutbah, Tabligh dan Dakwah, Metode pembelajaran : Ceramah Bervariasi

\begin{tabular}{|c|l|c|}
\hline 1 & Jumlah siswa & 31 \\
\hline 2 & Nilai maximum & 92 \\
\hline 3 & Nilai minimum & 85 \\
\hline 4 & Nilai rata-rata & 90.0 \\
\hline
\end{tabular}

Nilai Afektif kelas XI Mipa 5, Metode pembelajaran : Ceramah Bervariasi

Materi : Khutbah, Tabligh dan Dakwah

\begin{tabular}{|c|l|c|}
\hline 1 & Jumlah siswa & 31 \\
\hline 2 & Nilai maximum & 90 \\
\hline 3 & Nilai minimum & 82 \\
\hline 4 & Nilai rata-rata & 80.0 \\
\hline
\end{tabular}

Nilai Keterampilan kelas XI Mipa 5, Metode pembelajaran : Ceramah Bervariasi

\section{KESIMPULAN}

Metode Everyone Is Teacher Here merupakan strategi belajar yang mudah untuk mendapatkan partisipasi dari seluruh kelas dan pertanggung jawaban individu masing-masing. Strategi ini memberi kesempatan bagi setiap siswa untuk bertindak sebagai guru. Bagi siswa yang lainnya, melalui sebuah pertanyaan dari siswa yang ditulis dalam sebuah kartu kemudian siswa yang lainnya menanggapi dan memberi respon. Belajar berawal sesuatu yang baru akan lebih efektif jika siswa itu aktif dan terus bertanya ketimbang hanya menerima apa yang disampaikan oleh guru. Dalam proses pembelajaran berfikir, pengetahuan tidak
Materi : Khutbah, Tabligh dan Dakwah

\begin{tabular}{|c|l|c|}
\hline 1 & Jumlah siswa & 31 \\
\hline 2 & Nilai maximum & 94 \\
\hline 3 & Nilai minimum & 86 \\
\hline 4 & Nilai rata-rata & 85.3 \\
\hline
\end{tabular}

Tabel diatas adalah hasil nilai kognitif afektif dan keterampilan siswa, dimana terlihat jelas setelah menggunakan metode everyone is teacher here. Pada tabel nilai kelas XI Mipa 7 nilai dominan lebih bagus, suasana kelas pun begitu hangat dengan diskusi kecil antar siswa, kualitas pembelajaran PAI pun begitu baik dengan menggunakan metode everyone is teacher here. Sedangkan pada tabel peniaian siswa kelas XI Mipa 5 siswa mengalami penurunan nilai juga kualitas belajar dengan gaya yang sedikit monoton saat guru mengunakan metode ceramah bervariasi.

diperoleh sebagai hasil transfer dari orang lain, akan tetapi pengetahuan diperoleh melalui interaksi mereka dengan obyek, fenomena yang muncul. Aliran konstruktifisme menganggap bahwa pengetahuan tidak dapat ditransfer begitu saja dari orang seseorang kepada orang lain, tetapi harus diinterprestasikan sendiri oleh masing-masing individu. Oleh sebab itu metode pembelajaran Everyone Is Teacher Here adalah model pembelajaran yang menekankan kepada aktifitas siswa untuk mencari pemahaman akan obyek, menganalisis, dan mengkontruksinya sehingga terbentuk pengetahuan baru dalam individu. 


\section{DAFTAR PUSTAKA}

Depdiknas. UU Nomor 20 Tentang Sistem

Pendidikan Nasional. Jakarta; 2003

Oemar Hamalik. Proses belajar Mengajar.

Jakarta: Bumi Aksara 2004.
Melvin L. Siberman. Aktif Learning. Bandung; PT Nusamedia. Thn 2006.

Indriani Dwi Pursitasari, "metode everyone is teacher here pada materi ikatan kimia", Jurnal Akademia Kimia, Vol. 3, No. 2, 2014 